\title{
SOCIO-DEMOGRAPHIC DETERMINANTS OF RURAL HOUSEHOLDS EQUIPPED WITH DURABLE GOODS
}

\begin{abstract}
The aim of this article is to identify the types of rural households with the highest number of durable goods and an indication of the types of households with modern durable goods. We analysed the following characteristics of the household: household size, type of household biological and socio-economic status. Research methods were analysis of variance and correlation analysis. The results indicate the changes in consumer behaviour of rural residents in 2004-2014 and on the processes of modernization of consumption.
\end{abstract}

Keywords: households, rural area, durable goods equipment, consumption.

JEL codes: D12, D14, E21.

\section{Introduction}

Household's ownership of durable goods is contingent on the needs of household members. The need is understood as a certain psychophysical state of a human being, manifested in a subjective sense of lack and a desire for a specific good or state (situation, conditions) (Kocowski, 1979). Bywalec argues that the primary source of needs is the human body; it is followed by socio-cultural conventions dictated by the environment in which one lives, the fact that one functions within different social systems, such as a specific local community, an occupational group or work environment in which certain value systems have been adopted and are regarded as valid (Bywalec, 2010). When put to use, particular goods satisfy specific needs.

Jan Szczepański (1981) notes that the utility value of a specific good can be divided into its basic value and its accessory value. The basic value of a good is the main function that the good fulfills: for example, the basic utility of a mobile 
phone is the fact that it allows communication. The accessory value is the social status that the ownership of a particular brand of phone confers to its owner. The recent expansion of the luxury goods market in Poland testifies to the increasing importance of the accessory value. According to a report prepared by KPMG, interest in luxury goods continues to grow in Poland, as evidenced, for example by an increase in the sale of premium vehicles (BMW, Mercedes, Audi, Jaguar and Lexus), luxury jewelry and watches (Rynek dóbr..., 2015).

The number and quality of durable goods in households illustrates the needs of household members and reflects their social status. Durable goods are accumulated and consumed over long periods of time and form part of the household's durable assets. They attest to the affluence of the household and contribute to its members' wellbeing (Kędzior, 1992). In general, the larger the number of durable goods owned by a household, the greater its freedom in disposing of its income and the higher the average living standard (Bretyn, 2015; Zalega, 2012). Zalega (2010, 2012a) points out that the most affluent households are relatively highly saturated with durable goods. Furthermore, their quantity and quality seem to be constantly on the rise. A significant increase was observed first and foremost in terms of ICT equipment. When analysing the situation of young people's households, Włodarczyk-Śpiewak (2004) also points to growing expenditure on durable goods and, above all, modern technology. In contrast, Bylok (2006) notes that the modernization of households through furnishing them with durable goods takes place at a relatively slow pace in older people's households, i.e. the households of pensioners. These studies show that the financial situation of households and their demographics are an important factor impacting the consumption of durable goods by households. Another factor affecting the consumption of durable goods is the household's location.

The level of ownership of durable goods varies depending on the place of residence. In this respect, rural households seem to be at a disadvantage. This does not hold true only to the ownership of passenger cars, which is a consequence of a less developed public transport network and greater distances (Dąbrowska, Janoś-Kresło and Witek, 2012). It can probably be attributed also to differences in the material situation of all rural households compared to urban households; this, in turn, is a consequence of the socio-demographic characteristics of rural and urban communities. It seems, however, that the advancing homogenization of lifestyles has been blurring disparities between the city and the countryside.

Literature (Pronovost, 2006) points out that nowadays, houses/apartments equipped with a plethora of durable goods have begun to fulfill new social functions. As substitutes for cinemas, theatres, operas, places of education and physical recreation, they have become "places of art consumption". Globalization and technological progress have greatly influenced consumption choices made by households, which avail themselves more readily of modern durable goods (Janoś-Kresło, 2015). As a result of the observed individualization of lifestyles 
and the growing importance of the private sphere, more households are now equipped with goods that were once used only in public places (cinema, gym). A significant proportion of consumers, in particular women, people with disabilities and seniors engage in various types of activities at home. Already back in 2005, Smyczek and Sowa (2005) pointed out that such behaviours have a social resonance as, on the one hand, they bear witness to the "return to the family" as a certain value, and lead to the strengthening of family ties; on the other hand, however, they adversely affect social life and interpersonal relations. Although this view is partly legitimate, the increasing share of expenditure on catering services (Gutkowska and Piekut, 2016), particularly in the recent years, may be indicative of the burgeoning of social life.

Apart from globalization processes and the dynamic development of ICT, specific socio-demographic changes were observed: they manifest themselves, inter alia, in the shrinking size of households and the decreasing number of children, as well as changes in the occupational status on the labour market. These changes arguably affect the households' consumption of durable goods: for instance, there is no need for prams, changing tables, slides or sandboxes in childless households. As a consequence of a shift in terms of the source of income of the inhabitants of rural areas from agriculture to paid employment or self-employment, rural households are beginning to recognize new needs that arise from the observation of social groups that have, thus far, not been the object of their interest.

Households located in rural areas, which are the subject of this study, form a demographically and socially diverse group that comprises $40 \%$ of Polish households (GUS, 2016). The shrinking size of the rural household, a declining number of children per household and changes in the labour market reflected by the employment of members of rural households outside of the agricultural sector, combined with globalization processes and the unification of consumption, have influenced the consumption of durable goods.

The research problem discussed in this paper is the impact of socio-demographic processes and processes related to globalization and computerization on the behaviour of members of rural households on the market of durable goods.

The aim of this paper is to identify the types of rural households owning the greatest number of durable goods and those that consume state-of-the-art durable goods, as well as the types of households equipped with older-generation equipment.

Not only is such analysis cognitively interesting, but it also has a practical dimension and lends itself to application. Research results indicate changes in the consumption of durable goods influenced by social changes. They also reflect the preferences of consumers in rural households and their consumption patterns. 


\section{Data sources and analysis methods}

The source material consists of individual data collected by GUS in a survey of household budgets. The ownership of durable goods was researched in 2004 and in 2014. The choice of the research period for the analysis was dictated by the desire to discern and identify changes that took place in the period following Poland's accession to the European Union.

In the survey of household budgets carried out in 2004 and in 2014, the number of categories of durable goods changed. First of all, some durable goods were divided into a greater number of categories. For example, in 2004, television sets formed a single category; in 2014, they were divided into three categories: CRT TVs, MPEG-4 digital terrestrial television sets and other TVs. The adjustment of GUS's research methodology to the European standards and the availability of various new devices (e.g. smartphones, tablets) have translated into changes in the number of categories of durable goods during the analysed period. A detailed list of durable goods is provided in Table 1.

In the analysis of modern equipment of households, the following durable goods were taken into account: on the one hand, smartphones, laptops, tablets, electric cookers with ceramic hobs and multifunctional printers, which are regarded as modern appliances; on the other hand, CRT television sets, agitationtype washing machines, considered to be older-generation equipment. This decision of the researcher was dictated by changes observed on the durable goods market. The absence of certain devices or their low share in 2004 suggested that these are technologically advanced appliances, while a relatively significant decrease in the share of certain goods between 2014 and 2004 can be interpreted as the obsoleteness of these items.

Variance analysis served to determine the impact of socio-demographic and economic factors on rural households' ownership of advanced durable goods. Variance analysis also allowed the comparison of more than two types of households, defined on the basis of a single variable (univariate analysis) or multiple variables (multivariate analysis), and the examination of both the influence of individual factors and their interaction (Słaby, 2006). Univariate analysis was applied in the study. The dependent variable reflected households' ownership of durable goods, while independent variables were selected characteristics of a rural household, i.e. household size (number of people), level of education, age and gender of the householder.

This method is to allow for comparison of the dispersion, that is, the variance, of the dependent variable in the analysed types singled out on the basis of the values of independent variables (Aczel, 2000). The total variability of the results of the analysis is the sum of the squares of individual deviations from the mean (Wątroba, 2002). In the variance analysis, the total variance of analysis results is divided into two components, which correspond to intragroup and cross-group variability (Rozmus, 2009). The first component is the 
sum of the squares of mean group deviations from the general mean and it is the so-called sum of squared cross-group deviations. The second component is the sum of the squares of deviations of individual measurements within groups from the corresponding means, i.e. the intra-group sum of squares $\left(\mathrm{SS}_{\text {wewn }}\right)$. The sum of squares within the group is also called the sum of error squares and marked as $\mathrm{SS}_{\text {btad }}$, since the variation within the group is the result of an experimental error.

Two assumptions are made in the variance analysis. The dependent variable should be subject to normal distribution within groups. However, the F (FischerSnedecor) test is quite resistant to deviations from normality, and when the population is large enough, deviations from the normal distribution are not significant due to the central limit theorem, according to which the distribution of the mean from the sample leads towards normal distribution, independently of the distribution of the variable within the studied population (Wątrroba, 2004). The second condition for the application of the variance analysis assumes that variances within different groups of the system are equal (assuming homogeneity of variance). Nevertheless, it should be noted that F test statistics is also highly resistant to any breach of this assumption.

Correlation coefficients were used to measure the strength of the relationship between household characteristics and various durable assets. The correlation coefficient is based on the variance equation. It is a dimensionless quantity, with values within the range of $0 \leq \mathrm{e} \leq 1$, and thus its values are solely positive. It is equal to 0 , if the characteristics are uncorrelated and equal to 1 , if there is a functional dependence between the tested variables. As the correlation coefficient approaches 1 , the correlation becomes stronger.

The advantage of using the correlation coefficient lies in the fact that it does not depend on the regression, and can therefore be used with respect to both linear and curved regression. In addition, the correlation coefficient can be used with respect to two variables, one of which is immeasurable.

\section{Rural households' ownership of durable goods}

In Poland, households' expenditure on durable goods has been increasing every year. In 2000, it amounted to nearly PLN 36 per capita per month (GUS, 2001), while fifteen years later, it exceeded PLN 54 per capita (GUS, 2016a), while the share of expenditure on household equipment decreased during this period from 5.9 to $5.0 \%$. The increasing number and quality of durable goods (household appliances) affects the level of satisfaction of household members' needs, and, therefore, also the level of satisfaction with one's current life situation. The social report Diagnoza społeczna 2015 shows that the percentage of households that are not in the possession of certain durable goods due to financial difficulties is declining. Nowadays, it is rather the absence of the need than the lack of funds that explains the decision not to own certain appliances, 
in particular a landline telephone, a desktop computer, a car or a microwave oven (Czapiński and Panek, 2015).

Between 2004 and 2014, the consumption of durable goods by rural households significantly improved. The proportion of households that own a satellite or a cable television set has increased (Table 1). In 2004, less than one third of households owned such equipment; by 2014, this share had risen to more than $50 \%$. The ownership of the following devices has also increased: DVD players (from nearly 8 to almost 40\%), compact disc players (from 17 to over $70 \%$ ), computers with Internet access (from 9 to nearly 65\%), printers (from over 16 to over $34 \%$ ), private mobile phones (from 48 to over $92 \%$ ), automatic washing machines (from nearly 66 to over 90\%), microwave ovens (from approx. 26 to nearly 59\%) and dishwashers (from approx. 3 to over $23 \%$ ).

A decrease was observed in the number of older generation devices: for example, in 2004, more than $43 \%$ of households owned a sewing machine, while in 2014, the number was down to approx. 33\%; in 2004, agitation-type washing machines were owned by over $51 \%$ of households, while ten years later their number dwindled to less than $16 \%$.

At the same time, a progressive individualization of consumption was observed (Maciejewski, 2014). Goods such as a TV set, a car, a mobile phone or a laptop, once shared by family members, have become goods of individual consumption. In 2004, a single mobile phone was owned in $36 \%$ of rural households, while nearly $12 \%$ of households owned two or three mobile phones. A decade later, $23 \%$ of households owned one cell phone, while two or three were owned by as many as 54\% of households. Approximately $5 \%$ of rural households owned a car in 2004; in 2014, nearly $18 \%$ of rural households were in the possession of two passenger cars. 
Table 1

Share of rural households owning durable goods in 2004 and 2014

\begin{tabular}{|c|c|c|}
\hline Durable goods & 2004 & 2014 \\
\hline CRT TV receiver & \multirow{3}{*}{98.3} & 38.7 \\
\hline TV set for digital terrestrial television, MPEG-4 standard & & 52.6 \\
\hline Other types of TV sets & & 23.4 \\
\hline Cable TV equipment & \multirow{2}{*}{29.8} & 4.0 \\
\hline Satellite TV equipment & & 52.9 \\
\hline Receiver for digital terrestrial television, MPEG-4 standard & - & 31 \\
\hline Home cinema system & - & 11.1 \\
\hline DVD player & 7.9 & 39.8 \\
\hline Audio recording and playback system (home stereo) & 37.5 & 30.0 \\
\hline $\begin{array}{l}\text { Radio, cassette player, radio with CD player, } \\
\text { cassette and CD player }\end{array}$ & 16.6 & 70.3 \\
\hline Video camera & 2.7 & 6.3 \\
\hline Digital photo camera & \multirow{2}{*}{45.7} & 45.2 \\
\hline Other photo camera & & 6,0 \\
\hline Personal computer & - & 67.7 \\
\hline including laptops, tablets & - & 45.6 \\
\hline Computer with Internet access & 8.5 & 64.6 \\
\hline Computer without Internet access & 16.9 & 4.6 \\
\hline Printer & 16.4 & 34.4 \\
\hline Private mobile phone & 48.0 & 92.4 \\
\hline including smartphones & - & 25.1 \\
\hline Work mobile phone & 2.4 & 3.4 \\
\hline Agitation-type washing machine & 51.4 & 15.6 \\
\hline Automatic washing machine & 65.9 & 90.2 \\
\hline Vacuum cleaner & 90.6 & 93.4 \\
\hline Refrigerator & 97.7 & 98.5 \\
\hline Freezer & 54.4 & 46.0 \\
\hline Electric cooker with ceramic hobs & - & 8.4 \\
\hline Microwave oven & 25.8 & 58.9 \\
\hline Food processor & 56.5 & 64.9 \\
\hline Dishwasher & 2.5 & 23,1 \\
\hline Sewing machine & 43.1 & 32.5 \\
\hline Bicycle (not including children's bicycles) & 84.2 & 78.5 \\
\hline Motorcycle, scooter, moped & 6.6 & 11.6 \\
\hline Private car & 56.9 & 71.9 \\
\hline Business car & 1.0 & 1.5 \\
\hline Garage & 42.5 & 58.8 \\
\hline Summer house & 0.2 & 0.4 \\
\hline Recreational land & 3.3 & 4.5 \\
\hline
\end{tabular}

Source: own calculations based on unit data from the household budget survey. 


\section{Rural households' ownership of durable goods by the number of household members}

Rural households are gradually becoming smaller. In 2004, an average rural household had 3.6 members, while ten years later this number had dropped to 3.1 members. On the basis of the analysis of the relationship between the possession of durable goods by a rural household and the household size, it was found that the "household size" variable had a significant $(p<0.05)$ impact on the total number of durable goods held by the household. Correlation coefficients between the household size and the number of durable goods owned by it were high, ranging from 0.497 in 2004 to 0.621 in 2014, indicating a relatively strong correlation between the household size and its ownership of durable goods (Table 2).

As the number of household members increases, so does the number of goods, with the greatest difference between single and two-member households, as well as two and three-member households. In 2014, two-member households owned, on average, 6 durable goods more than single-member households; two-member households owned less than 5.3 items less than three-person households.

On the other hand, when we divide the number of goods by the number of household members, it turns out that the number of people is inversely proportionate to the number of durable goods owned, which is due to the economy of scale. A multi-member household does not need to buy more refrigerators, vacuum cleaners or cookers with ovens than a single-person household. In 2014, the number of durable goods per capita in single-member households was nearly 10 , in two-member households - approx. 7.5, in tree-member households - approx. 7 , and in those with four and more members -6 . As the number of single-person households increases, so does the demand for durable goods, as most households require a washing machine, a refrigerator or a computer.

In 2004-2014, an increase in the number of durable goods was observed in all types of rural households, which bears witness to the improvement in the quality of life in these households, as durable goods generally facilitate the performance of household chores. The greatest increase in the number of durable assets was recorded in households with four or more members.

Table 2

Average number of durable goods in rural households per household size in 2004 and 2014

\begin{tabular}{|c|c|c|}
\hline Specification & 2004 & 2014 \\
\hline 1 member & 6.9 & 9.9 \\
\hline 2 members & 10.5 & 15.9 \\
\hline 3 members & 13.6 & 21.2 \\
\hline 4 members & 15.5 & 24.0 \\
\hline 5 members and mere & 15.4 & 24.0 \\
\hline Correlative coefficient & 0.497 & 0.621 \\
\hline
\end{tabular}

Source: as for Table 1 . 
Household size has a significant impact on the number of new and old-generation appliances owned, with statistical significance of $\alpha=0,05(p<0,005)$. Correlation coefficient values between the number of household members and specific durable goods ranged between 0.093 in the case of electric cookers with a ceramic hobs and 0.377 in the case of laptops and tablets (Table 3).

Single-member rural households were most found to be most likely to own older-generation devices; nearly half of these households were equipped with a CRT TV set and a quarter of them owned an agitation-type washing machine. Few single-member households owned new-generation durable goods. The multifunctional printer was owned by $2 \%$ of single-member households, $3 \%$ owned a home cinema system, $4 \%$ - an electric cooker with ceramic hobs, and $5 \%$ - a smartphone. This fact is not surprising, given that the majority of singlemember rural households are those of the elderly (in 2014, the average age of a single-member rural household was 64.9, while in urban areas it was 58.8). First of all, they are less interested in modern devices, and secondly, they often do not need such equipment, e.g. printers.

Rural households' consumption of new-generation goods was growing as the number of household members increased, reaching the highest value in fourmember households. The percentage of households with 5 or more members and equipped with technologically advanced goods was slightly lower compared to four-person households, yet also relatively high. Furthermore, the share of oldgeneration goods in households with 5 or more members was greater than in households with 3 and 4 members.

3 and 4-member rural households own, on average, the most technologically advanced durable goods; the lowest number of them are owned by singlemember households. As previously mentioned, this is due to the demographic structure of the population that makes up the various types of households. Older people seem more attached to traditional devices, they are not interested in technological novelties and do not feel the need to acquire them. On the other hand, the equipment of 3- and 4-member households is more modern: first, because members of these households tend to be younger people, who are at the stage of furnishing their apartments and houses with durable goods, and secondly children and adolescents, who are most interested in modern technological developments and skilled in using innovative solutions, are generally also members of such households. 
Table 3

Percentage of rural households owning new and old-generation durable goods, by household size in 2014

\begin{tabular}{|c|c|c|c|c|c|c|c|}
\hline Specification & 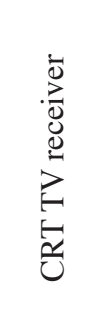 & 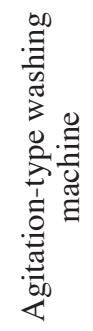 & 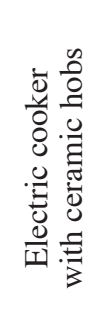 & 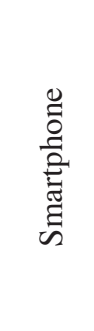 & 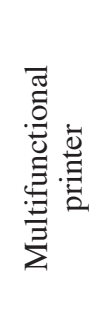 & 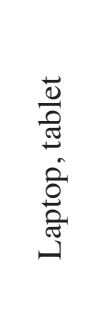 & 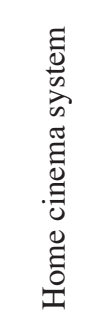 \\
\hline & \multicolumn{7}{|c|}{ percentage $(\%)$} \\
\hline 1 member & 49 & 25 & 4 & 5 & 2 & 11 & 3 \\
\hline 2 members & 39 & 16 & 8 & 11 & 12 & 29 & 7 \\
\hline 3 members & 35 & 12 & 10 & 31 & 26 & 58 & 15 \\
\hline 4 members & 32 & 12 & 12 & 40 & 32 & 64 & 17 \\
\hline 5 members and mere & 42 & 15 & 7 & 39 & 35 & 63 & 13 \\
\hline Correlative coefficient & 0.113 & 0.115 & 0.093 & 0.327 & 0.285 & 0.377 & 0.155 \\
\hline
\end{tabular}

Source: as for Table 1.

The increasing number of single-member households (Szukalski, 2016) can be expected to result in a growing demand for durable goods. This change obliges manufacturers to adjust certain devices to the needs of smaller households (e.g. refrigerators). Single-member rural households are largely represented by the elderly and, therefore, it is essential to adapt the functionality of devices to the capabilities of consumers from this demographic group (for example, mobile phones with large buttons). Some brands launch technologically advanced devices that are targeted at consumers theoretically less interested in a given product: for instance, the manufacturer of Nintendo Wii introduced computer games adapted for the elderly. By designing games for the elderly, the manufacturer has contributed to improving their health. It has been shown that the use of the console has become part of physiotherapy and rehabilitation of the elderly and those suffering from obesity (Nintendo..., 2016).

\section{Ownership of durable goods, by biological type of household}

Another statistically significant variable $(p<0.05)$ that impacts the total number of durable goods is the biological type of the household. "Household's biological type" relates to household members. A relatively high value of correlation coefficients was found between the ownership of durable goods by households and the biological type of household: in 2004, it stood at 0.485 and ten years later at 0.595 . 
Households of married couples with dependent children and other household members, i.e. multi-generational families, and other people with dependent children, as well as married couples with two or more dependent children owned the greatest number of household appliances. Single-member households and married couples without dependent children owned, on average, the smallest number of durable goods.

In 2004-2014, the total number of durable goods increased in all types of rural households. The highest increase was recorded in households with dependent children and, just as in the case of households of other people with dependent children, during the analysed period, the number of durable goods increased by 14.7 , among households of married couples with four and more children by 10.2 , and among households of married couples with dependent children and other household members by 9.4. At the other end of the spectrum, the number of durable goods owned by single-member households increased in the period between 2004 and 2014 by 3 items.

Table 4

Average number of durable goods owned by rural households, by household type in 2004 and in 2014

\begin{tabular}{lcc}
\hline \multicolumn{1}{c}{ Specification } & 2004 & 2014 \\
\hline Childless married couple & 10.8 & 16.3 \\
Married couple with a single dependent child & 14.5 & 22.5 \\
Married couple with 2 dependent children & 15.6 & 24.3 \\
Married couple with 3 dependent children & 14.9 & 24.3 \\
Married couple with 4 (or more) dependent children & 13.7 & 23.9 \\
Single mother with dependent children & 11.8 & 17.3 \\
Single father with dependent children & 13.0 & 17.0 \\
Married couple with dependent children and other household members & 16.4 & 26.4 \\
Single mother with dependent children and other household members & 13.4 & 21.0 \\
Single mother with dependent children and other household members & & 20.4 \\
Other persons with dependent children & 9.9 & 24.6 \\
Single-member household & 6.9 & 9.9 \\
Other & 13.0 & 19.4 \\
Correlative coefficient & 0.485 & 0.595
\end{tabular}

Source: as for Table 1. 
Based on the results of the analysis of the level of technological advancement of durable goods owned by households, as classified by the biological type of household, it can be argued that the presence of dependent children is conducive to a greater propensity of rural households to acquire new-generation devices. It was found that there are statistically significant differences between households, as classified by biological type, and new and old-generation devices at the level of $\alpha=0,05(p<0,0000)$. Correlation coefficient values were relatively high, ranging from 0.132 in the case of electric cookers with ceramic hobs to 0.376 in the case of laptops and tablets.

Households formed by couples with dependent children owned the greatest amount of ICT equipment. On the other hand, single-parent households with dependent children owned fewer ICT devices of this type, even if their number was greater compared to households without dependent children. Households consisting of a married couple with two children or one dependent child are most likely to own a home cinema system and an electric cooker with ceramic hobs.

The presence of children in the household affects the planning and purchasing of goods. In households without children, less attention is paid to innovative market products (Dąbrowska, Bylok, Kiełczewski and Ozimek, 2015). Two decades ago, it was found that the child acted as the initiator of purchases of durable goods, in particular of entertainment equipment (Uściński, 1996), but also it played an important role in the process of acquiring vehicles, television sets (Sowa, 1997) or the furnishing of the apartment (Lackman and Lanas, 1993). Present-day studies also highlight the role of children in the purchase of durable goods. The greatest influence of children on purchasing decisions was observed in the least and the most affluent families: in the former, children provide information and help select the right devices, while in the latter, children are free to choose the equipment that is bought for them (Sowa, 2011). Children and adolescents represent also an important segment of the market, as many of them earn or are given money that they have at their disposal (Smyczek and Sowa, 2003). According to GUS data, between 2004 and 2015, pocket money spending of households nearly doubled from PLN 5.83 per person in 2004 to PLN 10.19 per person in 2015 (GUS, 2005, 2016a). Children are increasingly becoming initiators and decision-makers in the process of acquisition of certain types of appliances, mainly ICT devices. 
Table 5

Percentage of rural households owning new and old-generation durable goods, by biological type of household in 2014

\begin{tabular}{|c|c|c|c|c|c|c|}
\hline Specification & 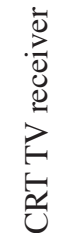 & 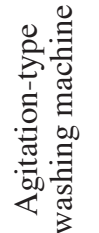 & 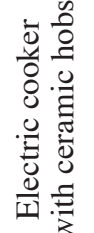 & 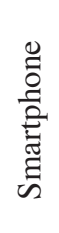 & 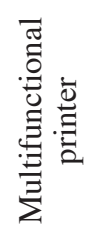 & 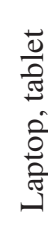 \\
\hline
\end{tabular}

\begin{tabular}{|c|c|c|c|c|c|c|c|}
\hline \multirow[b]{3}{*}{ Childless married couple } & & & & & & & \\
\hline & \multicolumn{7}{|c|}{ percentage $(\%)$} \\
\hline & 36 & 13 & 9 & 9 & 12 & 28 & 8 \\
\hline $\begin{array}{l}\text { Married couple with } \\
\text { a single dependent child }\end{array}$ & 26 & 8 & 14 & 40 & 34 & 67 & 21 \\
\hline $\begin{array}{l}\text { Married couple with } 2 \\
\text { dependent children }\end{array}$ & 25 & 8 & 15 & 43 & 36 & 68 & 20 \\
\hline $\begin{array}{l}\text { Married couple with } 3 \\
\text { dependent children }\end{array}$ & 30 & 10 & 10 & 38 & 38 & 63 & 16 \\
\hline $\begin{array}{l}\text { Married couple with } 4 \text { (or more) } \\
\text { dependent children }\end{array}$ & 37 & 15 & 7 & 29 & 31 & 60 & 10 \\
\hline $\begin{array}{l}\text { Single mother with } \\
\text { dependent children }\end{array}$ & 34 & 9 & 9 & 29 & 18 & 51 & 12 \\
\hline $\begin{array}{l}\text { Single father with } \\
\text { dependent children }\end{array}$ & 35 & 26 & 4 & 30 & 26 & 43 & 13 \\
\hline $\begin{array}{l}\text { Married couple with } \\
\text { at least one dependent child } \\
\text { and other household members }\end{array}$ & 44 & 16 & 8 & 41 & 34 & 65 & 13 \\
\hline $\begin{array}{l}\text { Single mother with dependent } \\
\text { children and other household } \\
\text { members }\end{array}$ & 45 & 15 & 4 & 32 & 22 & 52 & 9 \\
\hline $\begin{array}{l}\text { Single father with } \\
\text { dependent children } \\
\text { and other household members }\end{array}$ & 57 & 25 & 9 & 27 & 14 & 48 & 0 \\
\hline $\begin{array}{l}\text { Other persons with } \\
\text { dependent children }\end{array}$ & 48 & 14 & 3 & 37 & 22 & 55 & 13 \\
\hline Other & 45 & 21 & 6 & 23 & 18 & 46 & 8 \\
\hline Correlative coefficient & 0.178 & 0.156 & 0.132 & 0.326 & 0.294 & 0.376 & 0.185 \\
\hline
\end{tabular}

Source: as for Table 1. 


\section{Ownership of durable goods by socio-economic category of a household}

Another statistically significant variable $(p<0.05)$ that has had an impact on the number of durable goods in rural households was the socio-economic category of the household. Correlation coefficients between the socio-economic category and the number of durable goods ranged from 0.465 in 2004 to 0.520 in 2012, which is slightly lower than in the case of other variables, i.e. household size and biological type.

Households of self-employed persons and those employed in non-manual jobs were the most affluent. At the other end of the spectrum, in terms of the number of goods owned, were households of pensioners and those living on other social benefits. Statistically, households of self-employed persons and those employed in non-manual jobs have, highest income levels, which is conducive to greater freedom of consumption. In the case of households that own fewest durable goods, this situation can be attributed, inter alia, to their difficult financial situation. However, it is expected that, as the level of income increases, members of households equipped more modestly will strive to acquire new devices.

In each type of household, as classified by socio-economic category, an increase in the number of durable goods was observed. The largest increase in the number of durable goods was noted in the households of farmers and self-employed (over 8 items), and the slightest among pensioners (over 3 ).

Table 6

Average number of durable goods per rural household, by socio-economic category in 2004 and 2014

\begin{tabular}{lcc}
\hline \multicolumn{1}{c}{ Socio-economic categories of households } & 2004 & 2014 \\
\hline Manual workers & 13.8 & 21.3 \\
Non-manual workers & 17.3 & 24.5 \\
Employees-farmers & 15.5 & - \\
Farmers & 14.2 & 22.7 \\
Self-employed & 17.8 & 25.9 \\
Pensioners & 10.1 & 14.2 \\
Beneficiaries of disability pensions & 10.2 & 13.5 \\
Unemployed & 11.1 & - \\
Persons receiving social benefits & - & 13.7 \\
Persons relying on non-earned sources of income & - & 14.1 \\
Correlative coefficient & 0.465 & 0.517
\end{tabular}

Source: as for Table 1. 
Statistically, the socio-economic category has a significant impact on the ownership of technologically advanced and older-generation goods by households (statistical significance level $\alpha=0.05, p<0.0000$ ). The correlation coefficient value ranged from 0.156 in the case of CRT TV sets to 0.399 in the case of laptops and tablets, i.e. the link between the socio-economic category of the household and the ownership of new and old appliances was relatively strong compared to the previously discussed variables (household size, biological type).

The results of other studies (Dąbrowska, Bylok, Kiełczewski and Ozimek, 2015) indicate that the occupational status is an important determinant of consumer behaviour, since one's position within the social structure has a strong influence on one's attitude towards new products. Innovative consumers are, primarily, self-employed persons and those employed in administrative and office jobs. Farmers and retired people tend to be more traditional consumers, generally less interested in new products.

Table 7

Percentage of rural households owning new and old generation durable goods, by socio-economic category in 2014

\begin{tabular}{|c|c|c|c|c|c|c|c|}
\hline \multirow[t]{2}{*}{ Specification } & 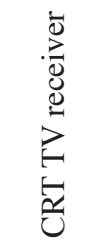 & 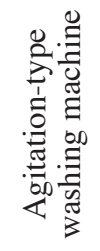 & 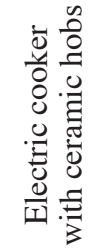 & 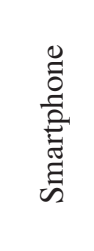 & 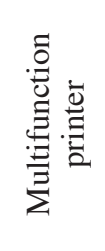 & 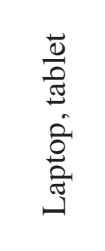 & 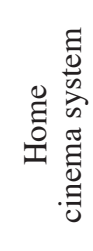 \\
\hline & \multicolumn{7}{|c|}{ percentage $(\%)$} \\
\hline Manual workers & 36 & 13 & 6 & 32 & 24 & 55 & 6 \\
\hline Non-manual workers & 27 & 7 & 16 & 42 & 36 & 72 & 16 \\
\hline Farmers & 44 & 21 & 6 & 27 & 29 & 48 & 6 \\
\hline Self-employed & 20 & 7 & 24 & 47 & 44 & 74 & 24 \\
\hline Pensioners & 46 & 21 & 5 & 7 & 8 & 20 & 5 \\
\hline Beneficiaries of disability pensions & 49 & 24 & 4 & 10 & 7 & 22 & 4 \\
\hline Persons receiving social benefits & 55 & 33 & 3 & 14 & 9 & 25 & 3 \\
\hline $\begin{array}{l}\text { Persons relying on non-earned } \\
\text { sources of income }\end{array}$ & 43 & 12 & 7 & 16 & 9 & 32 & 7 \\
\hline Correlative coefficient & 0.156 & 0.205 & 0.205 & 0.301 & 0.291 & 0.399 & 0.224 \\
\hline
\end{tabular}

Source: as for Table 1. 
Rural households of non-manual workers and of self-employed people own, on average, more modern devices than other types of households. Nearly three quarters of rural households, for which the main source of income is employment in non-manual jobs or self-employment, own laptops and tablets; they were owned by half of households of manual workers and farmers; no more than a third of the remaining types of households surveyed were also in the possession of these devices. On the other hand, older generation equipment was found mainly in households whose main source of income were social benefits or other non-earned sources of income as well as agriculture.

In other studies (Wrzochalska, 2006), it was noted that the households of farmers were better equipped than non-farming households, in particular with standard goods (vacuum cleaner, cassette player, landline telephone, washing machine, car, freezer) and those more technologically advanced (mobile phone, video recorder, satellite receiver, personal computer, food processor, microwave oven).

\section{Summary}

According to the research, many variables influence household consumption of durable goods. There is a relatively strong relationship between, on the one hand, the total number of durable goods and their technological advancement and, on the other hand, such variables as the size of the household, the presence of children and the socio-economic category. It can be stated that changes in the aquipment of rural households with durable goods are a consequence of sociodemographic processes, as well as globalization and computerization.

In the period between 2004 and 2014, the total number of durable goods increased in all types of households, classified according to the number of household members, its biological type and its socio-economic category. This fact illustrates the improving situation of rural households in Poland, as easier access to durable goods is synonymous with a greater comfort in life. Appliances such as washing machines and dishwashers, increasingly present in rural households, facilitate housework. Through widespread Internet access, members of rural households can avail themselves of both information and numerous services available online. Cultural and entertainment needs of a growing number of consumers from rural areas can now be met within the confines of their homes thanks to such appliances as home cinema systems or video cameras.

Differences in the ownership of durable goods by rural households are the consequence of demographic and socio-economic factors. The aim of this paper was to identify the types of rural households owing the greatest number of durable goods. Households with dependent children and households where the main source of income is self-employment or paid employment in non-manual jobs were found to be equipped with the greatest number of durable goods. The presence of children in the household, greater disposable income per capita 
and higher education levels were conducive to the ownership of more durable goods. This is primarily due to the needs arising within these households.

This paper was also to determine the types of households owning the most technologically advanced devices, on the one hand and, on the other, the types of households furnished with older-generation appliances. The presence of children in the household seems a strong determinant in the ownership of the most advanced appliances, such as smartphones, laptops, tablets or multifunctional printers. Higher occupational status of household members is correlated with a greater number of durable goods owned, which is most likely due to the desire to keep up with the social group with which members of such households identify, or to stand out among this group. Single-member households, which in rural areas tend to consist of the elderly, were found to have the greatest share of older equipment.

The increase in the number of durable goods in rural households testifies to the improved standard of living of rural consumers. The analysis of household ownership of durable goods bears witness to consumption development processes in rural households. The pace of these processes depends on demographic and socio-economic characteristics of individual rural households, with a significant impact of telecommunication techniques and technologies. 


\section{References}

Aczel, A.D. (2000). Statystyka w zarzadzaniu. Pełny wykład. Warsaw: Wydawnictwo Naukowe PWN, pp. 388-455.

Bretyn, A. (2015). Zmiany wyposażenia gospodarstw domowych w dobra trwałego użytku w Polsce a jakość życia. Studia Ekonomiczne, no. 209, pp. 19-32.

Bylok, F. (2006). Zachowania konsumpcyjne ludzi starszych w Polsce na początku XXI wieku. In: J. Kowaleski, P. Szukalski (ed.), Starość i starzenie się jako doświadczenie jednostek $i$ zbiorowości ludzkich. Zakład Demografii UŁ.

Bywalec, C. (2010). Konsumpcja a rozwój gospodarczy i społeczny. Wydawnictwo CH Beck.

Dąbrowska, A., Bylok, F., Kiełczewski, D., Ozimek, I. (2015). Kompetencje konsumentów. Innowacyjne zachowania. Zrównoważona konsumpcja. Warsaw: Polskie Wydawnictwo Ekonomiczne.

Dąbrowska, A., Janoś-Kresło, M., Witek, J. (2012). Wpływ ograniczeń finansowych na zakup dóbr trwałego użytku w miejskich gospodarstwach domowych. In: M. JanośKresło (red.), Gospodarstwa domowe w XXI wieku. Konsumpcja. Jakość życia. Warsaw: Oficyna Wydawnicza SGH, pp. 29-52.

Czapiński, J., Panek, T. (2015). Diagnoza Społeczna 2015. Warunki i jakość życia Polaków. Rada Monitoringu Społecznego. Vol. 9, issue 4, Warsaw.

GUS (2001). Budżety gospodarstw domowych w 2000 roku. Warsaw.

GUS (2005). Budzety gospodarstw domowych w 2004 roku. Warsaw.

GUS (2016). Budzety gospodarstw domowych w 2015 roku. Warsaw.

GUS (2016). Rocznik Statystyczny Rzeczypospolitej Polskiej 2016. Warsaw.

Gutkowska, K., Piekut, M. (2016). Korzystanie z usług gastronomicznych przez Polaków. Zeszyty Naukowe SGGW w Warszawie. Polityki Europejskie, Finanse i Marketing, no. 16(65), pp. 15-24.

Janość-Kresło, M. (2015). Kryzys z perspektywy konsumpcji polskich gospodarstw domowych. In: B. Mróz (ed.), Zmiany zachowań polskich gospodarstw domowych pod wpływem kryzysu. Warsaw: Oficyna Wydawnicza SGH.

Kędzior, Z. (1992). Gospodarstwa domowe - podmiot gospodarujący. Monografie i Syntezy, no. 70. Warsaw: IRWiK.

Kocowski, T. (1979). Globalna koncepcja potrzeb ludzkich. In: Rozwój społeczny - system oświatowy - potrzeby ludzkie. Problemy metodologiczne, Polska 2000, vol. 1.

Lackman, C., Lanasa, J. (1993). Family Decision-Making Theory. An Overview and Assessment. Psychology \& Marketing (March/April).

Maciejewski, G. (2014). Zachowania konsumentów w dobie postmodernizmu. Marketing i Rynek, no. 6, pp. 1129-1135.

Nintendo Wii - rewolucja siódmej generacji. (2016). Retrieved from: https://geezmo. pl/2016/02/03/nintendo-wii-rewolucja-siodmej-generacji/ (access data: 11.02.2017).

Pronovost, G. (2006). L'univers du temps libre et des valeurs chez les jeunes. Quebec: PUQ.

Rozmus, D. (2009). Analiza wariancji. In: E. Gatnar, M. Walesiak (ed.), Statystyczna analiza danych z wykorzystaniem programu $R$. Warsaw: Wydawnictwo Naukowe PWN.

Rynek dóbr luksusowych w Polsce. Edycja 2016. Raport KPMG (2016). KPMG.pl.

Słaby, T. (2006). Konsumpcja. Eseje statystyczne. Warsaw: Difin, pp. 42-43. 
Smyczek, S., Sowa, I. (2003). Modele rynkowych zachowań konsumentów. Katowice: Wyższa Szkoła Zarządzania Marketingowego i Języków Obcych w Katowicach,.

Smyczek, S., Sowa, I. (2005). Konsument na rynku. Zachowania, modele, aplikacje. Warsaw: Difin.

Sowa, I. (1997). Promocja - jak trafić do nastolatka? Aida Media, no. 1.

Sowa, I. (2011). Oddziaływanie interpersonalne w rodzinach młodych konsumentów w procesie dokonywania zakupu (na przykładzie wybranych dóbr). Studia i Materiały Polskiego Stowarzyszenia Zarzadzania Wiedza, no. 52, pp. 196-209.

Szczepański, J. (1981). Konsumpcja a rozwój społeczny człowiek. Wstep do antropologicznej teorii konsumpcji. Warsaw: PWE.

Szukalski, P. (2016). Prognoza gospodarstw domowych GUS z 2016 r. - co z niej wynika? Demografia i Gerontologia Społeczna - Biuletyn Informacyjny, no. 5, pp. 1-5.

Uściński, K. (1996). Rynek dziecięcych pragnień i marzeń. Aida Media, no. 2(21).

Wątroba, J. (2002). Wprowadzenie do analizy wariancji. Kraków: Statsoft.

Wątroba, J. (2004). Analiza wariancji. Materiały kursowe. Kraków: Statsoft.

Włodarczyk-Śpiewak, K. (2004). Wyposażenie młodych gospodarstw domowych w dobra trwałe jako jeden z elementów jakości życia na tle krajów Unii Europejskiej. In: A. Manikowski, A. Psyk (ed.), Unifikacja gospodarek europejskich: szanse i zagrożenia. Warsaw: Wydawnictwo Naukowe Wydziału Zarządzania Uniwersytetu Warszawskiego.

Wrzochalska, A. (2006). Poziom życia wiejskich rodzin rok po akcesji do Unii Europejskiej. Warsaw: IERiGŻ-PIB.

Zalega, T. (2010). Uwarunkowania zaspokojenia potrzeb w zakresie mieszkania i jego wyposażenia w gospodarstwach domowych wysokodochodowych. Master of Business Administration, 18(4), pp. 57-78.

Zalega, T. (2012a). Zmiany w wyposażeniu gospodarstw domowych w dobra trwałego użytku w okresie kryzysu. Zeszyty Naukowe SGGWw Warszawie. Ekonomika i Organizacja Gospodarki Żywnościowej, no. 98, pp. 91-108.

Zalega, T. (2012b). Konsumpcja dóbr trwałego użytku i zachowania przystosowawcze wśród polskich elit ekonomicznych w warunkach kryzysu. Nierówności społeczne a wzrost gospodarczy, no. 24, pp. 329-346. 
MARLENA PIEKUT

Politechnika Warszawska

Płock

\title{
SPOŁECZNO-DEMOGRAFICZNE DETERMINANTY \\ WYPOSAŻENIA GOSPODARSTW DOMOWYCH \\ W DOBRA TRWAŁE NA WSI
}

\begin{abstract}
Abstrakt
Opracowanie ma na celu identyfikację typów wiejskich gospodarstw domowych posiadajacych największa liczbe dóbr trwałego użytkowania oraz wskazanie na nowoczesność wyposażenia w różnych typach wiejskich gospodarstw domowych. Typy gospodarstw domowych zostały wyróżnione ze względu na cechy, takie jak wielkość gospodarstwa, typ biologiczny gospodarstwa domowego oraz kategoria społeczno-ekonomiczna gospodarstwa. Metodami badawczymi były analizy wariancji i korelacji. Wykazano znaczacy wzrost liczby dóbr trwałego użytku w gospodarstwach wiejskich między rokiem 2004 a 2014.
\end{abstract}

Słowa kluczowe: gospodarstwo domowe, wieś, dobra trwałego użytku, konsumpcja.

Accepted for print: 12.12.2014.

Unless stated otherwise all the materials on the website are available under the Creative Commons Attribution 3.0 Poland license. Some rights reserved to the Institute of Agricultural and Food Economics - National Research Institute.

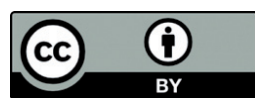

